\title{
THE ASSESSMENT AND EVALUATION IN TEACHING ENGLISH AS A FOREIGN LANGUAGE
}

\author{
Venny Eka Meidasari \\ Department of English Education, Faculty of Language \& Art \\ University of Indraprasta PGRI, Indonesia \\ E-mail: venny_xiaofen@yahoo.com
}

\begin{abstract}
APA Citation: Meidasari, V. E. (2015). The assessment and evaluation in teaching English as a foreign language. Indonesian EFL Journal, 1(2), 224-231
\end{abstract}

\begin{abstract}
This article is focusing on assessment and evaluation of English as a foreign language learning (EFL). These are essential components teaching and learning in English language arts. Both assessment and evaluation are the critical parts of effective literacy development; therefore, it is important for classroom teachers to know how to evaluate English language learners' progress. Without an effective evaluation program it is impossible to know whether students have learned, whether teaching has been effective, or how best to address student learning needs. The overall goal of assessment is to improve student learning. Assessment should always be viewed as information to improve student achievement. One could look at assessment and evaluation as the journey (assessment) versus the snapshot (evaluation). The assessment and evaluation literacy needs from the learner's perspective is also an important part of an instructional program. The needs of assessment and evaluation process can be used as the basis for developing curricula and classroom practice that are responsive to learners' needs. It encompasses both what learners know and can do and what they want to learn and be able to do. Learners need opportunities to evaluate their progress toward meeting goals they have set for themselves in learning English.
\end{abstract}

Key words: assessment, evaluation, foreign language learning, teaching, curriculum

\section{INTRODUCTION}

Assessment and evaluation are essential components of teaching and learning in English language arts. Without an effective evaluation program it is impossible to know whether students have learned, whether teaching has been effective, or how best to address student learning needs. The quality of the assessment and evaluation in the educational process has a profound and well-established link to student performance. Research consistently shows that regular monitoring and feedback are essential to improving student learning.

What is assessed and evaluated, how it is assessed and evaluated, and how results are communicated results send clear messages to students and others about what is really valued - what is worth learning, how it should be learned, what elements of quality are most important, and how well students are expected to perform.
Although the terms assessment and evaluation are often used interchangeably, in actuality they are two parts of the same process. Assessment is the process of gathering evidence of what the child can do. Evaluation is the process that follows this collection of data, including analysis and reflection, as well as decisions based on the data.

The assessment and evaluation of literacy needs from the learner's perspective is an important part of an instructional program. Although they may say they just want to "learn English," they frequently have very specific learning goals and needs; for example, to be able to read to their children, speak with their children's teachers, or to get a job. If their needs are not met, they are more likely to drop out than to voice their dissatisfaction. Therefore, using informal, self-assessment tools to gauge learner needs and goals is important. Also important, of course, is using formal assessment tools to gauge learner progress. 
The needs assessment and evaluation process can be used as the basis for developing curricula and classroom practice that are responsive to learners' needs. It encompasses both what learners know and can do and what they want to learn and be able to do. Learners also need opportunities to evaluate what they have learned-to track their progress toward meeting goals they have set for themselves in learning English.

\section{METHOD}

This is a qualitative research and the research is all about exploring issues, understanding phenomena, and answering questions aims to gather an in-depth understanding of human behavior and the reasons that govern such behavior. The object of the research is undergraduate students of Indraprasta University, semester three. However, the procedure used below is also adjustable for any level of language students.

\section{Procedure:}

\section{Planning the assessment}

In planning assessments to be taken by the general student population, including ELLs (English Language learner), the general principles of good assessment practices apply.

\section{Test purpose}

The purpose of a test must be clear in order for valid interpretations to be made on the basis of the test scores. Tests have different purposes. For example, one test may be used to evaluate students' readiness to advance to the next grade, while another evaluates students' need for remediation. It is also important to outline the specific interpretations that will be made based on the scores. For example, tests used as a criterion for high school graduation will affect students differently than tests designed to inform instructional decisions.

\section{Developing test items and scoring criteria Matching the task to the purpose}

The first step in developing a test item should be to link, directly to the test specifications and content standards, the content and skill that the item is supposed to measure. If the items require a high level of English proficiency, unrelated to the construct as defined, this will likely affect the scores for ELLs as well as students in the general population. For content area assessments, only include items that require high degrees of English proficiency if they are consistent with the assessment specifications. Examples of items that require a high degree of English proficiency are those that ask examinees to identify or provide specific definitions or terminology in English that are unrelated to the construct, or items that are evaluated based on the quality of the language in a constructed response.

Item writers and reviewers should work to ensure that all test items maintain specificity in their match to content guidelines. As part of the process of creating and reviewing test material to ensure that it is appropriate and accessible to examinees, it is important that item developers, state content review staff, and state review committees analyze each item critically to ensure that it only measures the intended construct.

\section{Defining expectations}

Because ELLs-just like students in the general population-come from a wide variety of cultural and educational backgrounds, item writers should not assume that students have had any previous experience with given tasks. For example, students should be told explicitly what type of response is acceptable for a constructed-response question, whether it is a paragraph, complete sentence, list, diagram, mathematical equation, and so on. Likewise, the criteria for the evaluation of the response should be made clear to the student. As this may add a significant reading load to the directions, information about how responses will be scored may be especially helpful if students receive it prior to the test. 


\section{Using accessible language}

Using clear and accessible language is a key component of minimizing constructirrelevant variance. However, do not simplify language that is part of the construct being assessed (e.g., the passages on a reading comprehension test or challenging vocabulary that is part of the construct of a subject area test). In other cases, though, the language of presentation should be as simple and clear as possible. Some general guidelines for using accessible language are provided below:

- Use vocabulary that will be widely accessible to students. Avoid colloquial and idiomatic expressions, words with multiple meanings, and unduly challenging words that are not part of the construct.

- Keep sentence structures as simple as possible to express the intended meaning. For ELLs, a number of simple sentences are often more accessible than a single more complex sentence.

- Avoid use of negatives and constructions utilizing not in the questions' stems and options as they can cause confusion, especially for ELLs.

- When a fictional context is necessary (e.g., for a mathematics word problem), use a simple context that will be familiar to as wide a range of students as possible.

- A school based context will often be more accessible to ELLs than a homebased context.

\section{Technique}

Divide the course into three phases:

- The first phase consists of sessions on effective teaching and introduction to Communicative Language Teaching (CLT); skills and sub skills of listening, speaking, reading and writing; grammar; vocabulary; Classroom management, educational technology and assessment. The sessions are conducted daily from 10 am to $5 \mathrm{pm}$. After the sessions, participants work in groups (each group consisting of four or five participants) and plan and prepare lessons for peer/team teaching with the help of a supervisor.

- The second phase is peer teaching, where trainees teach sections of their prepared lessons to their fellow students who act as students. The lessons are observed by a trainer or guest observer; and are followed by a feedback session.

- The third phase is 'real teaching' where participants teach a lesson with a group of proficiency course learners, and the lessons are observed by a trainer and followed by a feedback session.

\section{Strategies for Collecting Data}

The assessment/evaluation process involves the use of multiple sources of information collected in a variety of contexts. At the primary level, this research uses observation, work samples, and selfevaluation as tools in the process of assessment and evaluation.

\section{a) Observation}

Observation is the careful consideration and analysis of students' behavior and performance based on a broad range of contexts. In order to use observation effectively, teachers need to know a lot about students, language, and how students learn language, and they need to be able to interpret what they are observing. Students demonstrate what they think, know, and can do as they engage in various classroom activities that require the application of language processes and learning strategies. Teachers can learn a great deal about students by observing them engaged in such processes as reading, writing, and interacting with others.

Teachers who have not been accustomed to using observation as an assessment tool are sometimes uncertain about what they should be looking for. The key-stage and specific curriculum outcomes provide a framework for teachers to use in their observations. 


\section{b) Gathering observational data}

To make classroom observation manageable and effective, teachers need to focus their observations. Many teachers develop a systematic, rotational schedule. As well, they might choose a particular focus for their observations in each of these contexts as they work through their class.
Important and relevant information can also be gathered more incidentally. Teachers can also gather important data about students' attitudes, understandings, and knowledge through questioning students and talking with them. Although students may know or be able to do more than they put into words, conferences and other forms of dialogue can provide a wealth of information about students and their learning.

\section{Languages of Education Portfolio}

Aims:

- to provide a record of achievement in all languages of education

- to provide evidence of developing language competences needed for democratic citizenship

- to motivate learners to extend their range of language competences

- to ensure that the language needs of all pupils are being addressed

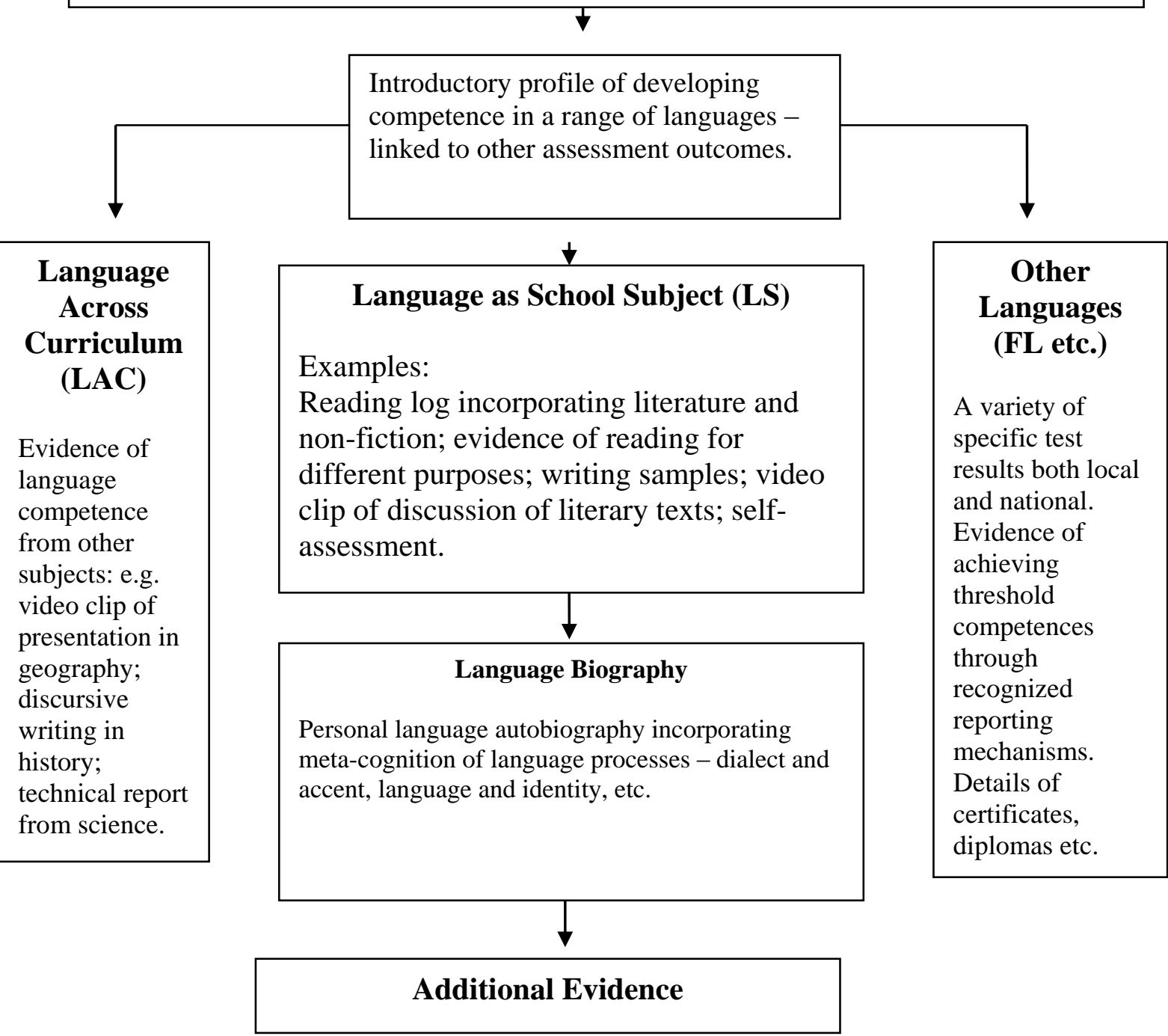

Waldemar Martyniuk, Waldemar, et. al. (2007). 


\section{RESULTS AND DISCUSSION}

Teachers of language as school subject are sometimes hostile to the idea of large-scale or formal testing on the grounds that it diminishes the subject and ignores the significance of context. This view needs to be considered.

a) Basic Principles of Assessment/Evaluation

- The primary purpose of assessment and evaluation is to inform teaching and to promote and encourage learning-to promote optimal individual growth. In order to provide information vital to the teachers, assessment and evaluation must be an ongoing and integral part of the teaching/learning process. It is one continuous cycle consisting of collecting data, interpreting data, reporting information, and making application to teaching.

- Assessment and evaluation must be consistent with beliefs about curriculum and classroom practices, and clearly reflect the various outcomes of the Kindergarten-3 English language arts curriculum, including those areas that cannot easily be assessed with pencil and paper (e.g., processes, attitudes, and values).

- The assessment/evaluation process involves the use of multiple sources of information collected in a variety of contexts. In order to make decisions about any aspect of a child's learning, the teacher observes evidence of that learning at different times, in different contexts, and in different ways. No one single behavior, strategy, activity, or test can provide a comprehensive picture of a child's learning.

- The assessment/evaluation process recognizes learners as active partners in their own learning and in the evaluation of that learning. Students are encouraged to reflect on their own growth, considering progress, strengths and weaknesses, and goals. b) What is Needs Evaluation and Assessment? Needs assessments and evaluation with adult English language learners examine the following aspects from the perspective of the learner:

- English language proficiency

- Native language literacy

- Literacy contexts in which the learner lives and works

- Learner need for native language translation or aid of an interpreter

- Learner wants and needs for functioning in specified contexts

- Learner expectations from the instructional program

The needs assessment and evaluation process focuses and builds on learners' accomplishments and abilities rather than deficits, allowing learners to articulate and display what they already know (Holt and Van Duzer, 2000). It is a continual process and takes place throughout the instructional program. The process can influence student placement, materials selection, curriculum design, and instructional practice (TESOL, 2003).

At the beginning of the program, needs assessment and evaluation might be used to determine course content, while during the program, it assures that learner goals and program goals are being met and allows for necessary program changes. At the end of the program, needs assessment and evaluation can be used for planning future directions for the learners and the program (Marshall, 2002). These same tools also may be used as a way to measure progress at the end of the year. However, for reporting outcomes to funders and external stakeholders, standardized assessments must be used.

\section{c) The Findings}

Utilizing First Language (L1:

Indonesia) as a facilitating device for EFL reading class is presented in the findings in this study. Questionnaires were distributed to 117 students that are shown in Table 1 below. 
Table 1: Students' responses to assessment in EFL reading class by utilizing L1

\begin{tabular}{|c|c|c|c|}
\hline No & Question Concerns & $\begin{array}{l}\text { Yes } \\
(\%)\end{array}$ & $\begin{array}{l}\text { No } \\
(\%)\end{array}$ \\
\hline 1 & Students' fondness for English in senior high school. & 68 & 32 \\
\hline 2 & Students' difficulties in learning English. & 99 & 1 \\
\hline 3 & $\begin{array}{l}\text { Students' experience in learning reading by retelling activity in } \\
\text { Indonesian language in senior high school. }\end{array}$ & 79 & 21 \\
\hline 4 & $\begin{array}{l}\text { Students' experience in learning reading by retelling activity in } \\
\text { Indonesian language in senior high school. }\end{array}$ & 83 & 17 \\
\hline 5 & $\begin{array}{l}\text { Students' easiness to understand a text in retelling activity from } \\
\text { English text to Indonesian language. }\end{array}$ & 97 & 3 \\
\hline 6 & Students' motivation in retelling activity in Indonesian language. & 90 & 10 \\
\hline 7 & $\begin{array}{l}\text { Students' difficulty in retelling activity using Indonesian language from English text } \\
\text { to understand text. }\end{array}$ & 17 & 83 \\
\hline 8 & $\begin{array}{l}\text { Students' easiness in retelling activity from English text by using English to understand } \\
\text { text. }\end{array}$ & 20 & 80 \\
\hline 9 & Students' difficulty in retelling activity by using English & 80 & 20 \\
\hline 10 & Students' comprehension on English text by retelling activity by utilizing English. & 14 & 86 \\
\hline
\end{tabular}

Tree questions in behavior aspects from question 2,3 , and 4 and seven questions in attitudinal aspects from question 1, 4, 6, 7, 8,9 , and 10 were equipped with reasons of each except question 2 and 4 due to the questions purpose for confirmation for students' learning English difficulty and retelling activity (RTA).

Most students (68\%) stated they had liked English since senior high school due to their willingness to be able to speak English well. Meanwhile some students (32\%) stated they disliked English due to their difficulties of vocabulary and sentences.

Almost all students (99\%) stated English is difficult subject due to their ignorance of vocabulary, pronunciation and their difficulties in grammar.

Many students (79\%) stated they had been familiar with RTA since senior high school school. Most students (83\%) stated it was not their first time to perform RTA by EFL use. These findings showed that RTA in EFL reading learning was not a strange teaching technique for them.

All students (97\%) stated RTA by Indonesian language provided them with easiness in understanding English reading text due to their L1 familiar meaning as an easier way to understand English reading text than EFL use.

Almost all students (90\%) stated RTA by Indonesian language provided them with high motivation due to their easiness in recalling reading content. The findings indicated that students' motivation for RTA by Indonesian language from their easiness in EFL text understanding.

Almost all students (83\%) stated they did not find difficulties in performing RTA from EFL reading text by Indonesian language due to their L1 meaning familiarities.

Almost all students (80\%) stated it was not easy to perform RTA by English language due to (1) their ignorance of vocabulary, pronunciation, and text meaning, (2) their difficulties in text understanding. The findings indicated the students' learning EFL difficulties in performing RTA in linguistic and comprehension.

Almost all students (80\%) stated it was difficult to perform RTA by English due to (1) their difficulties in translating and understanding text and memorizing text (2) their ignorance of vocabulary and pronunciation.

Almost all students (86\%) stated RTA by English did not show their text understandings due to their ignorance of vocabulary, words, text meaning and content.

Semi-structure interviews were conducted to focused group interview which consisted of six students. Two aspects of interview questions, in which question 2 in behavior aspect and questions 1, 3, 4, 5, and 6 
Venny Eka Meidasari

The Assessment and Evaluation in Teaching English As A Foreign Language

in attitudinal aspects, were analyzed by

coding technique that are shown in Table 2.

Table 2. Students' responses to assessment in EFL reading from interview

\begin{tabular}{|c|c|c|c|}
\hline No & Questions Concern & Response & Coding \\
\hline 1 & $\begin{array}{l}\text { Students' difficulties in text } \\
\text { understanding }\end{array}$ & $\begin{array}{l}\text { Yes. The students' difficulty in meaning, } \\
\text { vocabulary, and text understanding. }\end{array}$ & $\begin{array}{l}\text { X Difficult } \\
\text {-Easy } \\
\text { - Other }\end{array}$ \\
\hline 2 & $\begin{array}{l}\text { Students' experience about retelling } \\
\text { activity in EFL reading }\end{array}$ & $\begin{array}{l}\text { I ever joined retelling activities when I } \\
\text { was in senior high school }\end{array}$ & $\begin{array}{l}\text { X Ever } \\
\text {-Never } \\
\text {-Other }\end{array}$ \\
\hline 3 & $\begin{array}{l}\text { Students' easiness in retelling } \\
\text { activities in Indonesian language }\end{array}$ & $\begin{array}{l}\text { I felt easy to retell activity in Indonesian } \\
\text { language because it would be easy to } \\
\text { understand text. }\end{array}$ & $\begin{array}{l}\text { X Easy } \\
\text {-Difficult } \\
\text {-Confused }\end{array}$ \\
\hline 4 & $\begin{array}{l}\text { Students' difficulties in retelling } \\
\text { activity in English language }\end{array}$ & $\begin{array}{l}\text { I feel difficult to retell activities in English } \\
\text { because I found that vocabulary and } \\
\text { pronunciation were difficult so that I could } \\
\text { not speak English fluently }\end{array}$ & $\begin{array}{l}\text {-Easy } \\
\underline{X} \text { Difficult } \\
\text {-Strange }\end{array}$ \\
\hline 5 & $\begin{array}{l}\text { Students' comprehension in retelling } \\
\text { activity in English language. }\end{array}$ & $\begin{array}{l}\text { I could not understand it because I did not } \\
\text { know the meaning and the story content, }\end{array}$ & $\begin{array}{l}\text {-Comprehend } \\
\text { X Not } \\
\text { comprehend } \\
\text {-Confused } \\
\text {-Other }\end{array}$ \\
\hline 6 & $\begin{array}{l}\text { Students' preference retelling activity } \\
\text { in Indonesian or English language. }\end{array}$ & $\begin{array}{l}\text { I prefer Indonesian language because I } \\
\text { could comprehend the text easily }\end{array}$ & $\begin{array}{l}\text {-English } \\
\text { X Indonesian } \\
\text {-Other. }\end{array}$ \\
\hline
\end{tabular}

Students' text understanding difficulties revealed that they still found it hard to comprehend EFL reading text due their difficulty in vocabulary, meaning, and text understanding. These findings were confirmed by questionnaire responses which indicated that almost all students (99\%) found English as a difficult subject due the difficulty of vocabulary, pronunciation, and grammar.

Students' experiences about RTA in EFL reading class revealed that they had been familiar with RTA which were confirmed by questionnaire responses indicated almost all students $(83 \%)$ found it not strange to perform RTA in EFL reading class.

Students' easiness in RTA by Indonesian language revealed that RTA by L1 use provided them with easiness. These findings were confirmed by questionnaire responses indicated that almost all students (97\%) found it easy to perform RTA by Indonesian language due to their L1 meaning familiarities and text understanding. Students' difficulties in RTA by English language revealed that they found it more difficult to perform RTA by English than by Indonesian language due to their vocabulary, pronunciation, and meaning difficulty. These findings were confirmed by questionnaire responses which indicated that almost all students (80\%) found it not easy to perform RTA by EFL use. Students' comprehension in RTA by English language revealed that RTA by English did not show their text understandings due to their ignorance of meaning and story content. These findings were confirmed by questionnaire responses which indicated that almost all students (86\%) found RTA by English which did not show their text understandings due to text meaning and text understanding difficulties. Students' preference for RTA by Indonesian than by English language revealed 
that they preferred Indonesian language due to their easiness in text understanding. These findings were confirmed by questionnaire responses which indicated that almost all students (97\%) found it easier to perform RTA by Indonesian than by English language due to L1 word meaning familiarities.

\section{CONCLUSION}

Assessment is important but it is not without controversy and it can easily lead to polarised views and unhelpful tensions. This is particularly the case in the context of language as school subject (LS) because of the diversity and complexity of its aims.

Constructive debate around differences of opinion is always helpful, but too often disagreements about assessment become entrenched and unproductive. This happens for a number of reasons, including:a failure to recognise that assessment needs to fulfil a wide range of legitimate purposes; an assumption that a single assessment tool will be able to serve all needs; a lack of awareness that it is the use made of assessment, not necessarily the assessment process itself, that will largely determine its impact; and a tendency to search for universal solutions to assessment issues and neglect the significance of context.
With regard to EFL learning classroom interaction, it is suggested that English teachers should not force their students to fully utilize English in the learning classroom interaction for checking device in EFL classroom to avoid misunderstanding, confusion, and embarrassment. English teacher should employ L1 use to teach poor reader to guide their comprehension.

\section{REFERENCES}

Ellis, R. (1998). The evaluation of communicative tasks. In B. Tomlinson (Ed.): Materials Development in Language Teaching (pp. 217-238). Cambridge: Cambridge University Press.

Holt, D. \& Van Duzer, C. (2000). Assessing success in family literacy and adult ESL. Washington, DC: Center for Applied Linguistics.

Marshall, B. (2002). Preparing for success: A guide for teaching adult ESL learners. Retrieved from http://calstore.cal.org/store

Martyniuk, Waldemar, Fleming, Mike, Noijons, and José (2007). Evaluation and assessment within the domain of Language(s) of Education. Strasbourg. Language Policy Division, Council of Europe.

Teachers of English to Speakers of Other Languages, Inc. (2003). Standards for adult education ESL programs. Retrieved from http://www.tesol.org

Wajnryb, Ruth (1992). Classroom Observation Tasks: $A$ Resource Book for Language Teachers and Trainers. Cambridge: Cambridge University Press. 